\title{
Geophysical Observations in
}

Parts of the Grants District,

\section{McKinley County,}

\section{New Mexico}

\section{MHERAL RESTRERES LORATY}

\section{Derlarufued z, 10-6\%}

\section{Trace Elements Investigations Report 244}

UNITED STATES DEPARTMENT OF THE INTERIOR GEOLOGICAL SURVEY

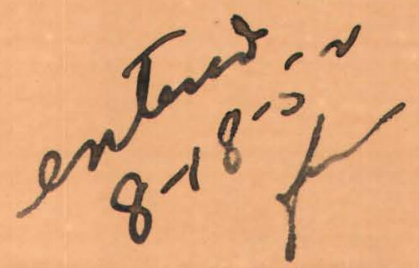


Geology - Mine ralogy

This document consists of 16 pages, plus 3 figures.

Series A

\section{UNITED STATES DEPARTMENT OF THE INTERIOR}

GEOLOGICAL SURVEY

GEOPHYSICAL OBSERVATIONS IN PARTS OF THE GRANTS DISTRICT, MCKINLEY COUNTY, NEW MEXICO*

By

Kenneth L. Cook and Calvin K. Moss

August 1952

Trace Elements Investigations Report 244

This preliminary report is distributed without editorial and technical review for conformity with official standards and nomenclature. It is not for public inspection or quotation.

*This report concerns work done on behalf of the Division of Raw Materials of the U. S. Atomic Energy Commission

When separated from Part II, handle Part I as UNCLASSIFIED 
USGS - TEI Report 244

GEOLOGY - MINERALOGY

Distribution (Series A)

No. of copies

American Cyanamid Company, Watertown ......... 1 Argonne National Laboratory ............. 1 Atomic Energy Commission, Washington ..........2 Carbide and Carbon Chemicals Company, I-12 Area .... . I Colorado Raw Materials Office (F. H. MacPherson) . . . . . I Division of Raw Materials, Grand Junction ....... 6 Division of Raw Materials, Grants ........... I Division of Raw Materials, Denver ........... I Division of Raw Materials, Hot Springs ......... I Division of Raw Materials, New York ......... 6 Division of Raw Materials, Salt Lake City ........ I Division of Raw Materials, Richfield ........... I Division of Raw Materials, Butte ........... I Division of Raw Materials, Washington.......... 8 Dow Chemical Company, Pittsburg .......... I Technical Information Service, Oak Ridge .......6 6

U. So: Geological Survey:

Mineral Deposits Branch, Washington ......... I Geochemistry and Petrology Branch, Washington ..... I Geophysics Branch, Washington .......... 10 Alaskan Geology Branch, Washington ........... I Fuels Branch, Washington .............. 1 V. E. McKelvey, Washington ............. I L. R。 Page, Denver .............. I R. P. Fischer, Grand Junction ............2 A. E. Weissenborn, Spokane ............. I J。 B。 Cathcart, Plant City .............. I J. F。 Smith, Jr, , Denver .............. I No Mo Denson, Denver .............. 1 R。 W. Swanson, Spokane .............. I C. B. Read, Albuquerque ............. . I A. H. Koschmann, Denver .............. . I E. H. Bailey, San Francisco ............ I A. Fo Shride, Tueson.................. I David Gallagher, Joplin ............. . I Carl Dutton, Madison .............. I R. A. Laurence, Knoxville .............. I $\mathrm{R}_{\text {. }}$ 。 Roberts, Salt Lake City ........... I

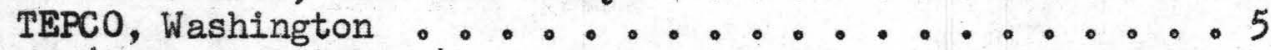
(Including master) 
CONTENTS

Page

Abstract ......................... 4

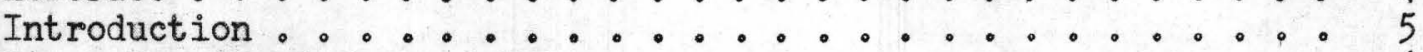

General geologic relationships .............. 6

Uranium deposits. ................... 8

Instrument and field techniques............... 10

Magnetic observations..................... . 11

Conclusions......................... 13

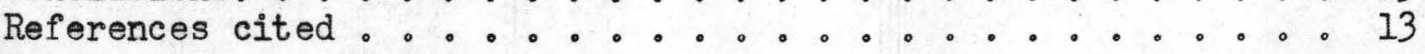

\section{ILLUSTRATIONS}

Figure 1. Map of surveyed area, near Grants, New Mexico, 1952 . 7

2. Portion of section 19, T. 13 N., R. 10 Wo, N. M. B.

and $P_{0} M_{0}$, near Grants, New Mexico.......... In envelope

3. Geologic cross section and geophysical profile along

traverse 8................. In envelope

4. Geologic cross section and magnetic profile along traverse A. ............... In envelope

5. Magnetic profile along traverse I... . . . . 14 
GEOPHYSICAL OBSERVATIONS IN PARTS OF THE GRANIS DISTRICT, MCKINLEY COUNIY, NEW MEXICO

By

Kenneth L。 Cook and Calvin Ko Moss

ABSTRACT

Geophysical observations near Haystack Mesa in the Grants district, McKinley County, New Mexico, had the dual objective of investigating the unusual occurrence of negative aeromagnetic anomalies in close association with airborne radioactivity anomalies, and of investigating other geophysical methods which might assist directly or indirectly in the search for uranium ores in the Grants district. Ground magnetometer tests indicate the apparent correlation shown in the airborne data is fortuitous。

Ground magnetometer and self-potential surveys on an experimental basis may be justified to test the applicability of these methods in future exploration. Aeromagnetic surveys would aid field geologic studies in locating concealed Tertiary intrusives, which may have affected ore localization.

Continuation of the airborne radiometric survey of the Todilto limestone outcrop is recommended to search for promising areas that might contain additional deposits. 


\section{INTRODUCTION}

In a combined airborne radioactivity and aeromagnetic survey in the vicinity of Grants, New Mexico, made by the U. S。 Geological Survey on May 28,1951 , an unusual association of radioactivity and negative magnetic anomalies was noted (Stead, 1951)。As it was thought that this association might reflect a genetic relationship between the uranium mineralization and the geologic structure causing the negative magnetic effect, further investigation seemed advisable。

On December 12 and 13, 1951, field examinations were made in secs。 19 and 25, T. 13 No, R。 10 Wo, No Mo Bo and $P_{0} M_{0}$, McKinley County, New Mexico. Brief ground magnetometer tests were also made in sec. 19. The magnetometer test area lies about 1 mile south of Haystack Mesa, about 6 miles north-northeast of the village of Bluewater (Bluewater lies about 12 miles northwest of the city of Grants), or about 20 miles northwest of Mount Taylor. Section 25 lies about 6 miles east-southeast of Haystack Mesa, about 9 miles northeast of the village of Bluewater, or about 15 miles northwest of Mount Taylor.

The field examinations had the dual purpose of investigating by geologic and ground magnetometer traverses the unusual occurrence of the observed negative magnetic anomalies in close association with observed radioactivity anomalies, and of investigating the possibility that other geophysical methods, in addition to the standard radioactive method already employed, might offer some additional help, either directly or indirectly, in the search for uranium ore in progress in the Grants district. 
The writer wishes to thank Mr. Irving Rapaport of the Atomic Energy Commission and his staff for their cooperation and help given in several conferences during the field tests and examinations. The work upon which this report is based was done on behalf of the Atomic Energy Commission.

\section{GENERAL GEOLOGIC RELATIONSHIPS}

The Grants district lies along the northern flank of the Zuni Uplift which is a northwestward-trending dome of early Tertiary age covering approximately 2,000 square miles (Towle and Rapaport, 1952). Sedimentary rocks of Jurassic and Cretaceous age are exposed in or near the area in which the field examinations were made. In sec。19, where the magnetometer tests were made, are the volcanic cone El Tintero (fig。 1 ) and an extensive lava bed that extends southward to the village of Bluewater. Mount Taylor lies about 20 miles southeast of El Tintero. Hunt (1938, p. 73) describes the area north of Bluewater, which includes the

El Tintero cone area, as follows:

Very recent flows of basalt are found in the valley of the Rio San Jose along the south border of the (Mount Taylor) volcanic field. These flows were given only casual attention, because none were supplied by vents within the (Mount Taylor) field. Some of the vents are along the east side of the Zuni Mountains, others are north of the village of Bluewater, and others are near Laguna Pueblo. The flows have exceedingly fresh surfaces, which, combined with their position in the valley bottom, make them appear as if they had been fllowing only yesterday. These flows are more ferromagnesian than most of the sheet eruptives of the Mount Taylor volcanic field. They consist of labradorite with a high percentage of olivine, slightly less augite, and some magnetite. 


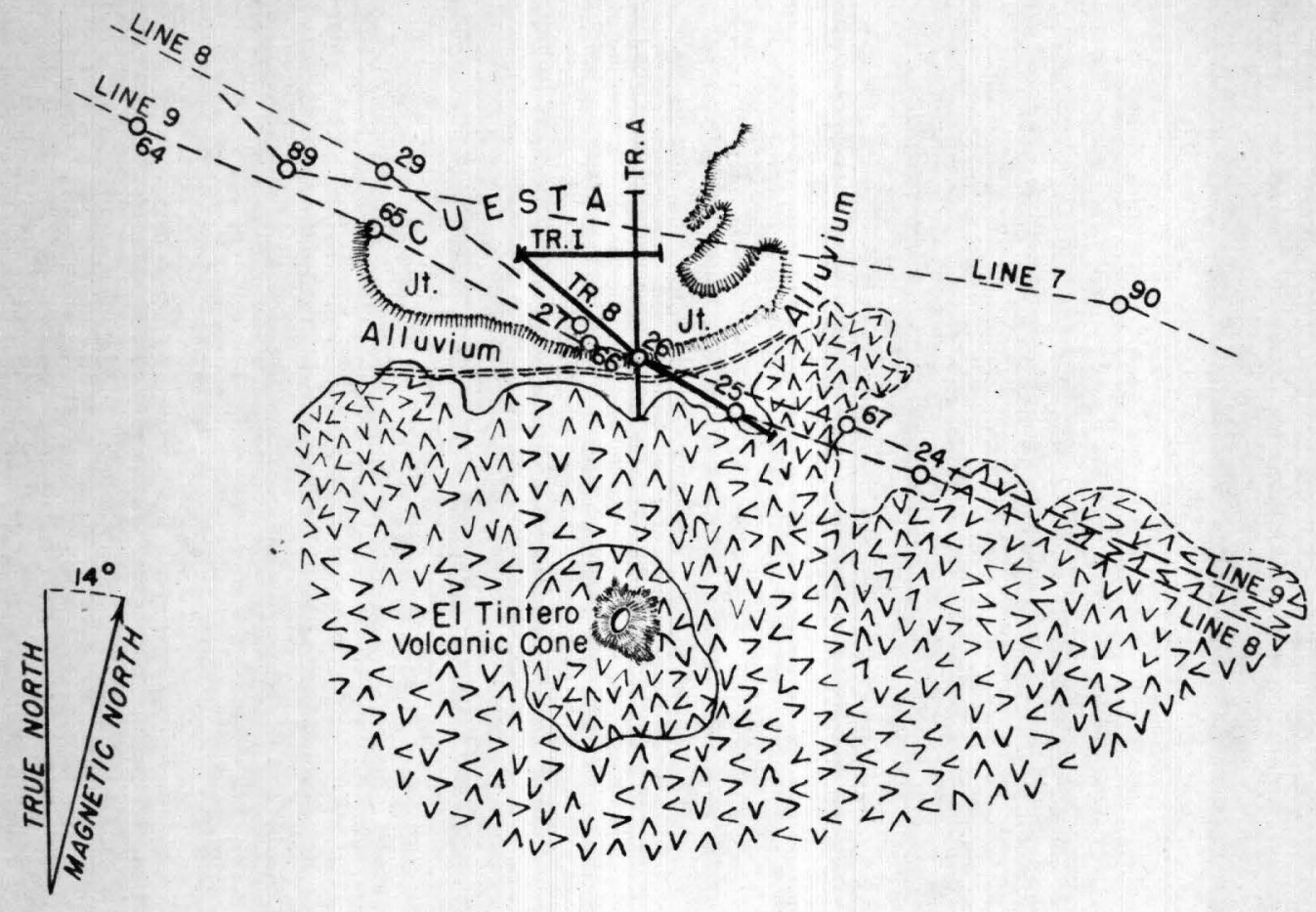

\section{EXPLANATION}

TR.A Magnetometer traverse

-0 LINE 9 Airborne traverse (Index number indicated)

$========$ Road

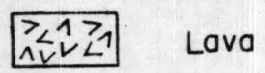

$\mathrm{Jt}$ Todilto formation (limestone)

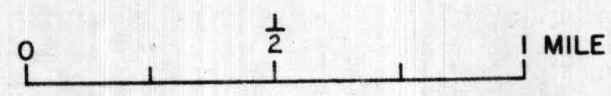

Figure I. - Map of surveyed area, near Grants, New Mexico-1952. 
In the test area in sec. 19 the prominent geologic features are: (1) the red southward-facing cliff of Entrada sandstone capped with Todilto limestone, which forms a bench or cuesta extending to the north away from the cliff and (2) El Tintero volcanic cone (figs, $I$ and 2). Exposures of the lava bed extend northward from El Tintero to within about 500 feet of the south face of the cliff (fig. 1). A mantle of alluvium, probably between 2 and 5 feet in average thickness, covers the Todilto limestone. Except at or near the edge of the cliff, the alluvium is probably sufficiently thick to mask completely the radioactivity of the ore within the Todilto limestone. At least locally in this area the alluvium or residual soil apparently contains some radioactive minerals.

\section{Uranium deposits}

The tests and field examinations discussed in this report were confined solely to the ore deposits in the Todilto limestone, which is the principal ore horizon in the Grants district.

Uranium deposits of the Grants district are described by Towle and Rapaport (1952) as follows:

\footnotetext{
..... Irregular, blanket-type uranium deposits are in terrestrial Jurassic sediments. The principal ore-horizon is the upper recrystallized portion of the Todilto limestone. This limestone erodes as benches one-half to three miles wide, enabling relatively cheap exploration and open-pit mining. Ore deposits have also been discovered in the sand lenses of the Morrison formation, 500 to 800 feet stratigraphically above the Todilto. The Morrison erodes into steep cliffs, necessitating more expensive exploration and mining methods.
} 
The uranium minerals in the Todilto are carnotite, tyuyamunite, and uranophane; finely disseminated pitchblende is found where the deposits are removed from the effects of superficial oxidation. Gangue minerals are pyrite, hematite, calcite, and traces of barite and fluorite. The sandstone ores in the Morrison contain carnotite and schroeckingerite, associated with limonite and organic material. The ore deposits are believed to have achieved their present form by the lateral percolation of slightly heated Tertiary waters. Uranium, however, may have originally been contributed during the Jurassic。

According to JoW。 Gruner (personal communication from Io Rapaport), hematite existing as a pseudomorphic replacement of pyrite is associated with the uranium minerals in sec. 19. Because of this replacement the ore is now impoverished of pyrite and relatively enriched with hematite.

In sec. 25, however, a normal amount of pyrite is found in the uranium ore, as replacement of the pyrite by hematite has not occurred to any considerable extent (personal communication from Io Rapaport). The "normal" amount of pyrite is probably considerably less than 1 percent in terms of percentage of the rock volume.

To the geophysicist, the problem of whether the uranium deposits may be genetically related to dikes, known to exist in the Grants district, is of paramount importance principally because the discovery of the dikes is possibly amenable to geophysical methods。

According to Rapaport (personal communication), however, no genetic relationship between the dikes and the ore bodies is known. He stated further that in the Laguna area, east of Grants, good exposures of dikes which cut the uranium bodies were found, thus indicating that some of the dikes are older than the uranium bodies. 
INSTRUMENT AND FIELD TECHNIQUES

A standard, temperature-compensated Askania vertical magnetometer with a sensitivity of 29 gammas per scale division was used for the ground surveys. Three traverses were made: one insofar as possible directly below airborne line 8 (Traverse 8 ); one trending north from the north edge of the lava, up and over the south face of the cliff, and approximately 1,600 feet along the Todilto limestone bench (Traverse A); and a third over a uranium body (Traverse I)。 About 140 magnetometer stations were occupied in a total traverse distance of about 7,500 feet. The magnetometer observations were made generally at 20 - or 25-foot intervals over exposed lava beds or in areas of steep magnetic gradients, at 25 - or 50-foot intervals over mineralized areas, and at 100- to 200-foot intervals over unmineralized areas or areas of gentle magnetic gradients. Distances along traverses were measured with a cloth tape.

The ground magnetometer traverses within the area of the Atchison, Topeka and Santa $\mathrm{Fe}$ Railway grid system were tied to this grid. The traverses beyond the area of this grid system were tied to conspicuous features on the ground, such as roads, cliffs, El Tintero volcanic cone, and isolated trees, which were plainly visible on the aerial photograph (approximate scale of the aerial photograph: 1.85 inch equals 1 mile). 
MAGNETIC OBSERVATIONS

Ground magnetometer traverse 8 is characterized by a gradual decrease in vertical magnetic intensity southeastward across the bench or cuesta toward the cliff, a minimum of about 1,400 gammas near 200E (about 250 feet south of the edge of the cliff) accompanied by a small maximum near $375 \mathrm{E}$, and a highly irregular intensity pattern for the remainder of the traverse (fig. 3)。

The irregular magnetic intensity pattern southeast of $375 \mathrm{E}$ is probably caused by lava lying immediately beneath the thin mantle of alluvium. Lava is exposed in some places along traverse 8 southeast of the road, and probably extends northwestward beneath the alluvium at least as far as $375 \mathrm{E}$.

The negative anomaly at $200 \mathrm{E}$ may be caused by a dike, with inverse remanent magnetization, or, equally plausibly, the negative anomaly may be the magnetic manifestation of the northwest edge of the lava bed. Small pieces of lava float were tested and found to reveal strong remanent magnetization, but no oriented specimens from outcrops were taken.

The aeromagnetic anomaly can be correlated reasonably well with the ground magnetic anomaly. The minimum of the aeromagnetic anomaly (fig。 3), which is about 600 gammas in magnitude, lies about 230 feet northwest of the minimum of the ground magnetic anomaly. The offset is probably caused largely by either errors of location 
or instrumental lag, or a combination of these factors; the amount of offset lies within the margin of location error for airborne surveys. As the airborne measurements are of total intensity measured from an arbitrary datum, there can be no direct comparison with the magnitude of ground measurements of vertical intensity。 The airborne radioactivity maximum (fig. 3), located at about 1030W, lies over or close to areas where uranium minerals are known to occur at shallow depths in the limestone forming the top of the cuesta. The radioactivity peak lies about 1,000 feet northwest of the aeromagnetic minimum and about 1,230 feet northwest of the ground magnetic minimum.

The general pattern of the magnetic profile of traverse A (fig. 4) is somewhat similar to that of traverse 8. Southward over the Todilto bench, the vertical magnetic intensity decreases and reaches a minimum of about 1,800 gammas at $150 \mathrm{~N}$, about 250 feet south of the edge of the cliff, then increases in magnitude to station $75 \mathrm{~N}$, where an irregular intensity pattern begins and persists to the south over the lava bed. The irregular intensity values indicate that the lava extends north at least as far as about 75N. As before, the negative center is due either to an inversely magnetized dike or is the magnetic manifestation of the north edge of the lava bed.

The trend of the magnetic negative anomaly, as sketched on figure 2 on the basis of traverses 8 and A only, is approximately 
east-northeast or parallel to the face of the cliff. The data are insufficient to interpret confidently the significance of the magnetic trend.

Ground magnetometer traverse I (fig. 5) was taken over a uranium body. There are slightly anomalous magnetic intensities in places on this traverse, but any interpretation of them is inconclusive because of the broken drill rods that were left in at least one of the many drill holes along the traverse。

\section{CONCLUSIONS}

The results of the ground magnetometer tests indicate that the apparent correlation between the negative aeromagnetic anomaly and the positive airborne radioactivity anomaly is probably fortuitous and cannot be attributed to a genetic relationship between uranium mineralization and the intrusion of dikes or the extrusion of the basaltic lava flow.

\section{REFERENCES CITED}

Hunt, C. B。, 1938, Igneous geology and structure of the Mount Taylor Volcanic Field, New Mexico: U. S. Geol。 Survey Prof。 Paper 189-B, p. 73, and Plate 7.

Stead, F. Wo, 1951, Airborne radioactive survey in the vicinity of Grants, McKinley and Valencia Counties, New Mexico: U。 S. Geol.Survey Trace Elements Memorandurn Rept. 161, unpublished, pp. $1-13$.

Towle, C. C., and Rapaport, I., 1952, Uranium deposits of the Grants district, New Mexico, A.I.M.E. Mining, Geology and Geophysics Division, Abstract of Technical Papers, 1952 Annual Meeting, abstract only, p. 19 . 
TRAVERSE I

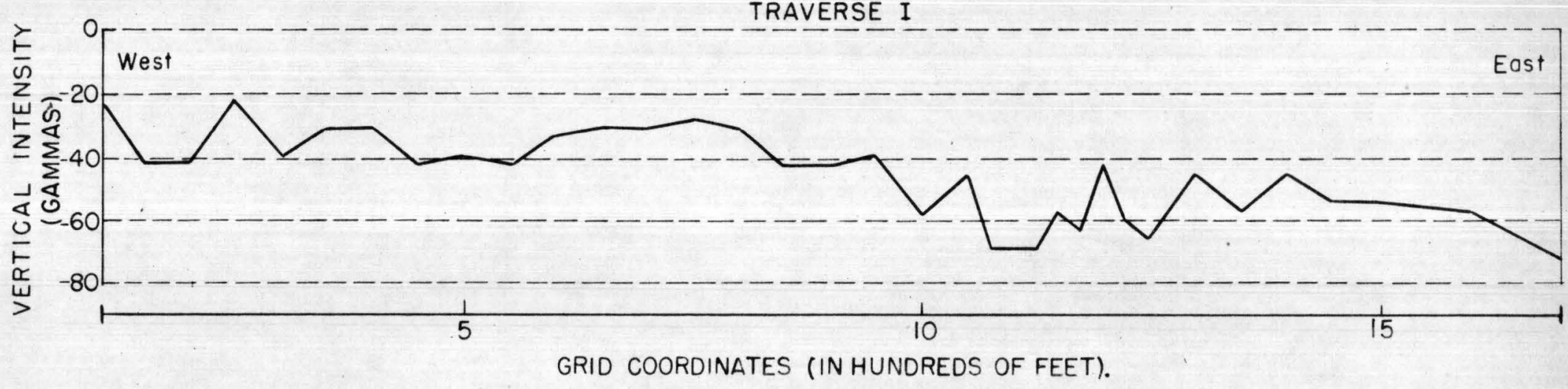

in

Figure 5. - Mognetic profile olong Traverse I. 


\section{$\frac{\text { OFFICIAL USE ONLY }}{15}$ \\ USGS TEIR-244, Part II \\ RECOMENDATIONS}

The existence of hematite in the ore and especially the shallow depth of the ore may justify some ground magnetometer surveys of an exploratory nature in the future. Magnetometer tests should be made first in a drilled-out area where lost tools have been carefully recorded, to ascertain whether recognizable magnetic anomalies exist over or adjacent to the uranium ore. Such magnetometer tests should be made first in sec. 19, where more hematite exists, and next in sec. 25. Unless recognizable magnetic anomalies over or adjacent to the ore are firmly established, no extensive ground magnetometer exploration will be justified. The experimental work discussed is not included in current Survey plans, but it will be considered if the Commission so requests. Towle and Rapaport have suggested that the ore deposits have achieved their present form by the lateral percolation of slightly heated Tertiary waters. If this is true the location of concealed Tertiary intrusives might help to indicate the probable sources of the heat and the direction of migration of the waters. Airborne magnetic surveys would aid greatly in locating such intrusives; and, if the Commission wishes, the Survey will consider undertaking such surveys.

To date all large airborne radioactive anomalies found over the Todilto limestone can be corelated with the occurrence of uranium OFFICIAL USE ONLY 


\section{OFFICIAL USE ONLY}

16

minerals in the ground. Airborne radioactive anomalies found occasionally over the lava beds are apparently not as diagnostic, however, as they may be the cumulative effect of widespread traces of radioactive material. In many places the mantle of alluvium masks the radioactive effect of uranium-bearing bedrock, and uranium ore bodies, without accompanying airborne radioactive anomalies, have been found (personal communication from I. Rapaport).

Continuation of the airborne radiometric survey of the outcrop of the Todilto, completed thus far only in the Grants district, is recomrended on a regional scale to outline promising areas that might contain additional deposits. Such a survey would cost about $\$ 15,000$, and if approved by the Commission, might be undertaken by the Survey in the 1953 field season.

Brief experimental self-potential traverses probably should be made to determine whether or not this method can be applied to the Grants-type deposits in future exploration. The electrical tests should be made preferably in the early spring when the moist ground will afford better contact for the nonpolarizing electrodes. The probable great depth to the ground water table, the small percentage of pyrite, and other factors diminish the likelihood that substantial, consistent, self-potential anomalies will be found associated with the ores. The shallow depth of the ore and the presence of pyrite, however, seem to justify at least some brief experimental electrical tests. None are planned now but they will be considered if the Commission desires. 